This is a revised personal version of the text of the final journal article, which is made available for scholarly purposes only, in accordance with the journal's author permissions. The full citation is:

Walker, M., Iyer, K., Heaven, S., and Banks, C. J. (2011). “Ammonia removal in anaerobic digestion by biogas stripping: An evaluation of process alternatives using a first order rate model based on experimental findings". Chemical Engineering Journal. 178(15), 138-145 DOI: 10.1016/j.cej.2011.10.027

\title{
Ammonia removal in anaerobic digestion by biogas stripping: an evaluation of process alternatives using a first order rate model based on experimental findings
}

\author{
M. Walker*, K. lyer, S. Heaven, and C. J. Banks \\ *Corresponding author - School of Civil Engineering and the Environment, University of Southampton, \\ Southampton, SO17 1BJ, UK
}

\begin{abstract}
The feasibility of biogas stripping to remove ammonia in the anaerobic digestion of source segregated food waste was investigated. It was found in batch experiments that ammonia could be removed from digestate and that the removal followed $1^{\text {st }}$ order kinetics with respect to total ammonia nitrogen concentration. Increasing temperature, biogas flow rate and initial $\mathrm{pH}$ all increased removal rates. Using kinetic data gathered in these experiments allowed the integration of ammonia stripping with an anaerobic digestion plant to be modelled for different configurations. Four scenarios were identified: post digestion, in situ, side-stream and pre-digestion ammonia removal relating to where in the process the ammonia stripping was performed. The modelling showed that in situ ammonia removal may be best able to reduce indigester ammonia concentrations over a wide range of organic loading rates whereas pre-digestion showed most promise in terms of application due to the flexibility to control each part of the process separately. Further experimental work is required into these scenarios to confirm their viability.
\end{abstract}

\section{Keywords}

Anaerobic Digestion (AD), Ammonia, biogas, stripping, source-segregated food waste (SSFW)

$\begin{array}{ll}\text { Abbreviations } \\ \text { ABPR } & \text { Animal by-products regulations } \\ \text { AD } & \text { Anaerobic digestion } \\ \text { Defra } & \text { Department for Environment, Food and Rural Affars } \\ \text { FW } & \text { Food waste } \\ \text { HRT } & \text { Hydraulic retention time } \\ \text { OLR } & \text { Organic loading rate } \\ \text { SSFW } & \text { Source segregated food waste } \\ \text { TAN } & \text { Total ammonia nitrogen } \\ \text { VFA } & \text { Volatile fatty acid } \\ \text { VS } & \text { Volatile solids }\end{array}$




\section{Introduction}

Food waste $(\mathrm{FW})$ is a major waste stream and its disposal can be problematic due to its high moisture content, bulk density and biodegradability [1]. Furthermore it can contain pathogens, is subject to animal by-products regulations (ABPR) (EC 1069/2009) and in Europe its disposal to landfill is being phased out under the EU Landfill Directive (99/31/EC). When collected as a mixture with municipal and commercial wastes it can complicate or prevent recovery of other potentially valuable materials through contamination by contact with the FW. There is therefore increasing interest in the separate collection and management of source segregated food waste (SSFW) with an emphasis on further recovery of value from this material. The high moisture content and calorific value of FW make suitable for anaerobic digestion (AD) which produces biogas, a biofuel, and the nutrient content makes the digestate suitable to apply to agricultural land as a fertiliser [2].

Despite the advantages of anaerobic digestion (AD) as a treatment technology for SSFW there are potential operational problems due to the high proportion of proteinaceous material in the raw waste [3]. The anaerobic degradation of proteins leads to the release of ammonia which is a necessary nutrient for many organisms in the digester, but in elevated concentrations can be inhibitory, especially in its non-ionised form free ammonia $\left(\mathrm{NH}_{3}\right)$ [4]. Most evidence suggests that the acetodastic methanogens which degrade acetate and produce methane and carbon dioxide are more sensitive to free ammonia than hydrogenotrophic methanogens $[5,6]$, with inhibitory concentrations of Total Ammonia Nitrogen (TAN) reported in the range of 759-4000 $\mathrm{mg} \mathrm{N} \mathrm{I}^{-1}[3,4,7-9]$.

Digesters fed on SSFW have been shown to exhibit symptoms of ammonia toxicity, but these problems may take a long time to cause process failure. The elevated ammonia/ammonium concentration provides buffering capacity that allows digester operation at higher concentrations of volatile fatty acids (VFA) than would be possible in a less buffered system [10-12]; it is only when this buffering capacity is broken by acid accumulation that the $\mathrm{pH}$ drops to a point where conditions are unfavourable for methanogenesis. This behaviour has also been seen in the digestion of other nitrogen-rich materials such as cattle slurry [13] and slaughterhouse waste [14]. It would be advantageous to be able to manage the ammonia concentrations in $A D$ such that the problems of its accumulation are avoided, in turn preventing the build-up of VFA. Furthermore, the ability to manage the ammonia content of a digestate will allow higher rates of application in nitrogen sensitive zones under the EU Nitrates directive (91/676/EEC), and balancing of the overall nutrient composition.

Ammonia removal from wastewater and animal slurry has been well studied. Methods used indude struvite precipitation [15]; biological ammonia oxidation and denitrification [16]; electrochemical conversion [17]; microwave [18] and ultrasound treatment [19]; and air stripping [20]. The latter is a proven concept for the removal and recovery of ammonia from slurries and wastes: air is blown through the liquid and the free ammonia transfers into the gas phase and can then be captured by absorption downstream. It has been found that the most rapid removal occurs at high temperature, high gas flow rate and high $\mathrm{pH}$ [20-22]. The importance of these parameters can be explained using $\mathrm{pH}$ equilibrium and phase change theories: $\mathrm{pH}$ modifies the ammonia removal behaviour on a chemical basis, by shifting the equilibrium between free ammonia, the volatile form, and ammonium salts which are non-volatile. Temperature alters the same equilibrium slightly, with an increase causing a greater fraction of free ammonia to be present in the digestate; and also has a physical effect in that it increases the saturated vapour pressure of the free ammonia, thus increasing the driving force which allows volatilisation into the gaseous form. Flow rate of gas has no chemical effect on the balance of free/ionic ammonia but instead changes the available surface 
interface between the liquid and gaseous phases within the stripping system, such that an increase in flow rate leads to an increase in reaction rate (in this case volatilisation and removal of ammonia).

The aim of this work was to investigate the possibility of in-situ ammonia removal in the anaerobic digestion process itself, as it is during this stage that ammonia is released through hydrolysis and also the point where accumulation occurs leading to process inhibition. The most promising method for direct integration with an anaerobic digestion plant was thought to be gas stripping using biogas as the stripping gas. This has the potential advantage of removing ammonia whilst maintaining an anaerobic environment and keeping the carbon dioxide in equilibrium with the dissolved carbon in the digestate, thus avoiding $\mathrm{pH}$ change as demonstrated by de la Rubia et al [23].

The paper presents data from ammonia stripping experiments using digestate from an anaerobic digester treating source segregated food waste [11]. The kinetic data was then used to model possible methods of integrating this ammonia management technology into an anaerobic digestion plant. The experiments and modelling in this work were carried out at three temperatures commonly associated with anaerobic digestion; $35^{\circ} \mathrm{C}$ (mesophilic), $55^{\circ} \mathrm{C}$ (thermophilic) and $70^{\circ} \mathrm{C}$ (pasteurisation) with pH modified only when this could be feasibly done during the digestion process.

\section{Materials and methods}

\subsection{Batch removal of ammonia using biogas stripping from food waste digestate}

Two digestates were used, both taken from an anaerobic digester treating source segregated food waste (Biocycle, Ludlow, UK). The first sample had a TAN concentration of approximately $8000 \mathrm{mg} \mathrm{N}^{-1}$ in which the $\mathrm{pH}$ changed from 8.5-9.3 on storage between stripping experiments. The second sample had a TAN concentration of approximately $6000 \mathrm{mg} \mathrm{N} \mathrm{I}^{-1}$ and a $\mathrm{pH}$ of 8.1-8.2.

Ammonia removal was carried out in a water jacketed heated glass column of total volume three litres connected to a closed loop biogas recirculation system with condensate and ammonia traps (Figure 1). The system was primed with a standard biogas mixture of $65 \%$ methane, $35 \%$ carbon dioxide (BOC, UK) and gas was circulated by a peristaltic pump. A biogas storage bag was included in the loop to provide a reservoir for additional biogas produced by the digestate during the course of an experiment. Two litres of digestate were used in each stripping test, with samples taken during the run to monitor changes in $\mathrm{pH}$ and to assess the kinetics of the ammonia removal. At the end of each experiment the TAN concentration in the digestate, water, acid and condensate traps was measured to determine the distribution of ammonia within the system. Where digestate $\mathrm{pH}$ was modified this was done using $10 \mathrm{M} \mathrm{NaOH}$.

Experiments were carried out at $35^{\circ} \mathrm{C}, 55^{\circ} \mathrm{C}$ or $70^{\circ} \mathrm{C}$, at gas flow rates from $0.125-0.750$ litres of biogas per litre of digestate per minute $\left(\mathrm{I} \mathrm{I}^{-1} \mathrm{~min}^{-1}\right)$, with and without initial $\mathrm{pH}$ adjustment. The experimental conditions for each run are given in Table 1. An additional experiment was carried out in which the digestate was spiked with acetic and propionic acid to give concentrations similar to those found in the experiments carried out by de la Rubia et al [23] in which the $\mathrm{pH}$ profile during stripping differed from that seen in this study. The VFA addition experiment was performed at $70^{\circ} \mathrm{C}, 0.375 \mathrm{I}^{-1} \mathrm{~min}^{-1}$ and without $\mathrm{pH}$ modification. 
TAN concentration was determined using a Kjeltech steam distillation unit according to the manufacturer's instructions (Foss Ltd, UK). Sample $\mathrm{pH}$ was measured using a pH probe connected to a Jenway $3310 \mathrm{pH}$ meter (Jenway, UK). The $\mathrm{pH}$ meter was calibrated before use with buffer solutions ( $\mathrm{pH} \mathrm{4,7}$ and 9.2 general purpose grade, Fisher Scientific, UK). Total solids (TS) and volatile solids (VS) content were determined according to Standard Method 2540 G [24]. Volatile fatty acids (VFA) were quantified in a Shimazdu GC2010 gas chromatograph (Shimadzu, Milton Keynes, UK), using a flame ionization detector and a capillary column type SGE BP-21.

\subsection{Modelling the integrated ammonia removal and anaerobic digestion process}

A model was developed to simulate the integration of ammonia stripping with anaerobic digestion based on the following assumptions:

1. Ammonia is removed in the stripping reactor such that the TAN decreases exponentially $\left(1^{\text {st }}\right.$ order kinetics). This was shown experimentally in the biogas stripping experiments.

2. The digester and tank volumes are dimensionless and the results from laboratory-based experiments can be scaled up.

3. Ammonia is released into the digester immediately by the incoming food waste; in reality this is not the case, as there is some delay while proteins are hydrolysed; but this time is short relative to the typical retention times in anaerobic digestion.

4. The TAN concentration upon digestion is a characteristic of the feedstock and therefore the TAN of completely hydrolysed food waste digestate is a constant independent of other operating characteristics: in this research $6000 \mathrm{mg} \mathrm{N} \mathrm{I}^{-1}$ was used. This assumes no hydrolysis inhibition.

5. The digester, mixing tank, ammonia stripping reactor and pasteuriser are completely mixed.

6. The food waste is homogenous and of constant volatile solids (VS) content (217 g VS kg fresh matter was used in this work) with a density of $1000 \mathrm{~kg} \mathrm{~m}^{-1}$, allowing the relation of mass flow and hydraulic characteristics of the systems.

The model was applied to four scenarios that are represented in Figure 2 and described below, with the following common characteristics: biogas is used as the stripping gas; it is bubbled through the digestate before entering an ammonia recovery stage; the biogas production of the plant is unaffected by the stripping process as it is not consumed during ammonia removal.

\section{Scenario 1 - Post digestion ammonia removal}

The ammonia stripping reactor is placed after the main anaerobic digester and is operated at $70^{\circ} \mathrm{C}$, and additionally acts as a pasteurisation stage. Under the ABPR pasteurisation is obligatory when using mesophilic digestion and to combine it with ammonia removal minimises the energy requirements of the combined process. A proportion of the output digestate from this stage is returned to the start of the process, and mixing of this ammonia-depleted recyclate with incoming food waste reduces the digester ammonia concentration. In this scenario the hydraulic retention time (HRT) of the plant is set by the incoming organic loading rate (OLR) but the digester HRT can be altered by changing the ratio of recycled digestate to incoming food waste. For maximum ammonia reduction in the digester it is preferable to have a high recycle ratio. This presents an operational problem, however, as the recycled digestate has been pasteurised and therefore does not return active anaerobic biomass to the system. The limitation is therefore the minimum digester HRT, which sets the maximum amount of digestate that can be recycled. For process stability a minimum digester HRT of 30 days was assumed. The stripping conditions used in the simulations were $70^{\circ} \mathrm{C}$, biogas flow rates of $0.5-0.625 \mathrm{I} \mathrm{I}^{-1} \mathrm{~min}^{-1}$ and $\mathrm{pH}$ modification to 14 (as in experimental runs 20.1 and 20.2), giving an ammonia removal time constant of 4 hours, the stripper was operated for 24 hours per batch fill. 
Scenario 2 - In situ ammonia removal

The digester is gas mixed and the whole digester becomes a stripping reactor, with ammonia captured in the mixing gas which is subsequently sent to the ammonia removal stage. In this scenario, since there is no digestate recycling, the HRT of the process is set by the OLR. The ammonia stripping system in this case operates at the temperature and $\mathrm{pH}$ of the digester, and only the gas flow rate can be changed. The stripping was simulated at $35^{\circ} \mathrm{C}$, biogas flow rate of $0.375 \mathrm{II}^{-1} \mathrm{~min}^{-1}$ and no $\mathrm{pH}$ modification (as per experimental run 0.1 ), giving an ammonia removal time constant of 595 hours.

\section{Scenario 3 - Side-stream ammonia removal}

This configuration is similar to scenario 1 except that the stripping reactor and pasteuriser are separate. Stripping takes place as a side-stream process to the main digestion, in batch or continuous mode, with the transfers of digestate between the stripping reactor and main digester being of equal volume but other conditions being flexible: the residence time in the ammonia stripping reactor can be altered by changing the flow of digestate between the two reactors or by changing their relative sizes. The conditions of the stripping process may have implications for the active biomass in the digester, similar to the case where a high temperature and high flow rate process is used as in scenario 1 . In the simulations the relative size of the stripping reactor was varied between $1 / 10$ and $1 / 100$ of the main digester. It was assumed that the stripping reactor was filled with digestate daily and operated constantly for a 24-hour period, with stripping conditions of $70^{\circ} \mathrm{C}$, biogas flow rate of $0.375 \mathrm{Il}^{-1} \mathrm{~min}^{-1}$ and no $\mathrm{pH}$ modification (as per experimental run 6.1), giving an ammonia removal time constant of 17.7 hours.

\section{Scenario 4 - Pre-digestion ammonia removal}

This scenario relies on the release of ammonia during a short anaerobic hydrolysis stage, with subsequent removal in a stripping reactor. As in scenario 3 the design is flexible and would need optimisation to the degradation characteristics of the food waste. Parameters that can be varied are: the residence time in the hydrolysis stage; the residence time in the stripping reactor; and the conditions of ammonia stripping. In initial simulations the effectiveness of the hydrolysis was varied by changing the TAN concentration leaving this step between 0-6000 $\mathrm{mg} \mathrm{N} \mathrm{I}^{-1}$ i.e. between no hydrolysis and complete hydrolysis of the proteinaceous fraction of the food waste. Stripping was modelled at $70^{\circ} \mathrm{C}$, biogas flow rates of $0.5-0.625 \mathrm{II}^{-1} \mathrm{~min}^{-1}$ and $\mathrm{pH}$ modification to 14 (as per experimental runs 20.1 and 20.2), giving an ammonia removal time constant of 4 hours. In the later simulations, and for comparison with the other scenarios, a hypothetical plant was designed to give a hydrolysis tank HRT of 2 days and a batch time in the ammonia stripper of 8 hours at an OLR of $5 \mathrm{~kg} \mathrm{VS} \mathrm{m}^{-3} \mathrm{~d}^{-1}$. In these simulations hydrolysis and therefore TAN production was assumed to follow $1^{\text {st }}$ order kinetics with a time constant of $0.35 \mathrm{~d}^{-1}$.

The characteristics of each scenario were investigated separately before being compared under given conditions for OLR of 1-6 $\mathrm{kg} \mathrm{VS} \mathrm{m}^{-3} \mathrm{~d}^{-1}$.

\section{Results and discussion}

\subsection{Batch removal of ammonia using biogas stripping from food waste digestate}

The results of the ammonia stripping experiments are shown in table 1. For each experimental run an ammonia removal time constant was calculated for using the measurements of TAN and fitting an 
exponential decay curve (i.e. $1^{\text {st }}$ order kinetics): these are tabulated along with the respective correlation coefficients $\left(r^{2}\right)$. An example of this process is shown in Figure 3 for experimental run 3.1, where the time coefficient of the equation is 0.031 and the reciprocal of this gives the ammonia removal time constant of 32.3 hours. The correlation coefficients $\left(r^{2}\right)$ for these curve fits ranged from 0.73 to 1.00 but in most cases were above 0.95 indicating that an exponential decay function gave a satisfactory representation of the physical behaviour. This allows quantitative comparison between experimental runs with different initial and final conditions.

The ammonia removal time constants for experimental runs without $\mathrm{pH}$ modification were plot ted against biogas flow rate in Figure 4. The data follows the trends previously observed by de la Rubia et al [23]: an increase in biogas flow rate (or in temperature, when compared with runs 0.1 and 1.1 in Table 1) led to an increase in the ammonia removal rate. The range of flow rates in these experiments, up to $0.75 \mathrm{II}^{-1} \mathrm{~min}^{-1}$, was greater than previously used, however. It can be seen that increasing the gas flow rate above $0.375 \mathrm{II}$ ${ }^{1} \mathrm{~min}^{-1}$ has little impact on the rate of removal as saturation is reached. The time required for cessation of ammonia removal at $70^{\circ} \mathrm{C}$ was between 30 and 80 hours.

Addition of alkali to modify the initial $\mathrm{pH}$ was shown to have a strong effect on the TAN removal kinetics, as seen in experimental runs 11-14 and 18-20. The time for removal decreased from 30-80 hours to around 420 hours. This is in agreement with the theory that increasing the $\mathrm{pH}$ leads to a greater proportion of free ammonia and therefore to more rapid removal. At high alkali dosages experimental problems were encountered due to excessive foaming, and antifoam (J-QUELL 19, J1 Technologies, UK) was used to prevent this.

Table 2 shows an example of the partitioning of the TAN on a concentration basis for runs 12.1 and 12.2, demonstrating that the ammonia captured in the condensation and water traps can reach very high concentrations; TAN concentrations of 35 and $21 \mathrm{~g} \mathrm{~N} \mathrm{I}^{-1}$ respectively. Additionally the results show that most of the ammonia had been removed from the gas flow before the acid trap, suggesting that it could be omitted from the system without having a major impact of the process. This would reduce risks and cost associated with acid use on an industrial scale.

\subsection{Effect of VFA on ammonia stripping}

The results in Table 1 show a difference in behaviour of the two digestates under similar ammonia stripping conditions. This was thought to be due to the higher VFA concentration in digestate 2, although the digestates 1 and 2 had different TS contents of 5.50 and $3.14 \%$ respectively.

In the experiment where digestate 2 was spiked with VFA, the effect of this on the ammonia stripping can be clearly seen in Figure 5. The VFA reduced the $\mathrm{pH}$ of the digestate, causing a pH swing as the ammonia was removed. This prevented the removal of ammonia below a TAN of $4300 \mathrm{mg} \mathrm{N} \mathrm{I}^{-1}$, compared with a final TAN concentration of $1090 \mathrm{mg} \mathrm{N} \mathrm{I}^{-1}$ when no VFA was added. This explains some apparent discrepancies between the previous work and current findings [23], and is an important result since it has implications for the use of ammonia stripping to recover food waste digesters that have already accumulated high concentrations of VFA: in these conditions gas stripping is less effective and is unlikely to reduce TAN concentrations to less than $4000 \mathrm{mg} \mathrm{N} \mathrm{I}^{-1}$.

The main reason for differences in ammonia removal from both digestates under similar conditions was thought to be the different VFA concentrations in these digestates, although it is also possible that 
digestate TS could influence this. The interaction between the gas bubbles and the digestate may be affected by the digestate physical characteristics, including its solids content and viscosity, but further investigation of this was outside the scope of the current work.

\subsection{Modelling the integrated ammonia removal and anaerobic digestion process}

\section{Scenario 1 - Post digestion ammonia removal}

Figure 6 shows accumulation in a digester with initial TAN concentration of $500 \mathrm{mg} \mathrm{N} \mathrm{I}^{-1}$, representing a digester inoculated with municipal sewage sludge digestate. Organic loading rates of $1-6 \mathrm{~kg} \mathrm{VS} \mathrm{m}^{-3} \mathrm{~d}^{-1}$ were modelled with an ammonia removal time constant of 4 hours corresponding to a temperature of $70^{\circ} \mathrm{C}$ and a biogas flow rate of $0.375 \mathrm{II}^{-1} \mathrm{~min}^{-1}$. The retention time of the digester was set to 30 days by altering the ratio of recycled digestate to incoming feedstock, making the volume of digestate recycled between 6.230.21 times the volume of the fresh feed. The steady state TAN concentration was reached after 100-120 days and increased from 831 to $4977 \mathrm{mg} \mathrm{N} \mathrm{I}^{-1}$ with increasing loading rate from 1 to $6 \mathrm{~kg} \mathrm{VS} \mathrm{m}^{-3} \mathrm{~d}^{-1}$. This corresponds to reductions in digester TAN concentrations of $86-17 \%$ respectively relative to a digester without ammonia stripping.

The variation in performance can be attributed to the different volumes of recycled digestate. The ratio of recycled digestate to fresh FW feed is chosen such that the HRT in the digester is at a safe minimum, which in this case was set at 30 days. At $1 \mathrm{~kg} \mathrm{VS} \mathrm{m}^{-3} \mathrm{~d}^{-1}$ the whole system HRT was 217 days and the recycle ratio (volume recycled: volume fresh feed) was 6.23, meaning that fresh food waste with an TAN production potential of $6000 \mathrm{mg} \mathrm{N} \mathrm{I}^{-1}$ is diluted with 6.23 volumes of digestate with a TAN concentration only $0.2 \%$ of that in the digester. At the highest OLR, however, the dilution is only 0.21 volumes which led to the higher steady state TAN concentration. The final loading limit on the system is $7.24 \mathrm{~kg} \mathrm{VS} \mathrm{m}^{-3} \mathrm{~d}^{-1}$, at which point the HRT of the whole system is 30 days and no digestate could be recycled without reducing the digester HRT below this value.

The post digestion removal scenario requires in the pasteurisation of excess digestate, since some of the output from the stripper/pasteuriser is recycled, and will therefore increase the heat load of the anaerobic digestion plant. In the worst case, at $1 \mathrm{~kg} \mathrm{VS} \mathrm{m}^{-3} \mathrm{~d}^{-1}$ the heat load of the stripper/pasteuriser is increased by a factor of 7.23 relative to scenario 2 . This may be acceptable in some circumstances where sufficient waste heat is available.

\section{Scenario 2 - In situ ammonia removal}

Figure 7 shows the results for OLR of 1-6 $\mathrm{kg} \mathrm{VS} \mathrm{m}^{-3} \mathrm{~d}^{-1}$ with an initial TAN concentration of $500 \mathrm{mg} \mathrm{N}^{-1}$. The ammonia removal time constant in this case was 595 hours corresponding to a digester temperature of $35^{\circ} \mathrm{C}$ and a biogas flow rate of $0.375 \mathrm{Il}^{-1} \mathrm{~min}^{-1}$. Despite the constant being two orders of magnitude higher than in the post digestion stripping scenario, the final TAN concentrations at all loading rates are lower. The TAN concentration in the digester was $629-2510 \mathrm{mg} \mathrm{N} \mathrm{I}^{-1}$ equating to removals of $90-58 \%$ respectively relative to no intervention at the same OLR. In this scenario the ammonia removal is simply related to the HRT of the system: at shorter retention times (higher OLR) the digestate spends less time in the stripping system (the digester) and therefore the final TAN concentration is higher. The retention time of the digester for scenario 2 was set by the incoming volume of food waste (i.e. by the OLR) and varied between 217 and 36 days. 
In contrast to scenario 1 there is no additional heat load on the plant but pumping requirements are much greater, by a factor of 15 (as the stripping reactor in scenario 1 is $1 / 30$ the size of the digester and operates at twice the specific biogas flow rate).

\section{Scenario 3 - Side-stream ammonia removal}

This configuration is similar to the post-digestion removal except that it offers a greater degree of flexibility by operating the stripping system independently of the pasteuriser. Figure 8 shows the results of the modelling where the stripping reactor was modelled as a semi-continuous process filled and discharged once every 24 hours. The volume of the stripping system relative to the digester volume was adjusted in a range between $1 / 10$ and $1 / 100$. In each case the batch time of the stripping reactor was constant at 24 hours, equivalent results could be obtained by adjusting the batch time and keeping the volume of the stripping system constant. The system was modelled using an ammonia removal time constant of 17.7 hours equivalent to a temperature of $70^{\circ} \mathrm{C}$ and a biogas flow rate of $0.3751 \mathrm{I}^{-1} \mathrm{~min}^{-1}$. As was expected the results showed that the larger the stripping system, relative to the size of the digester, the lower the resulting concentration of TAN. At an OLR of $3 \mathrm{~kg} \mathrm{VS} \mathrm{m}^{-3} \mathrm{~d}^{-1}$ the effect of changing the stripping system volume from $1 / 100$ to $1 / 10$ was to reduce the TAN concentration from 3984 to $991 \mathrm{mg} \mathrm{N} \mathrm{I}^{-1}$, corresponding to a change in TAN removal from $34-83 \%$ relative to no stripping.

For comparison scenario 3 was modelled for a single case and compared on a performance basis (digester TAN concentration) with all the other scenarios (Figure 9). The stripping system, with a volume of $1 / 30$ the digester, was filled daily and operated continuously between filling operations which were assumed to be instant. Again stripping was modelled with an ammonia removal time constant of 17.7 hours as per experimental run 6.1. The results of this simulation are that for OLR of $1-6 \mathrm{~kg} \mathrm{VS} \mathrm{m}^{-3} \mathrm{~d}^{-1}$ the TAN concentration was $942-3166 \mathrm{mg} \mathrm{N}^{-1}$ corresponding to TAN removals of $84-47 \%$ respectively relative to no intervention.

It should be noted that the mode of operation of the side-stream ammonia stripping system may have implications for the biological stability of the system since the digester effective HRT can go below 30 days (including both the effluent and stripping system flows). Further testing would be required to ascertain whether stable digestion could be maintained with the stripping system in operation and with associated disruptions to the biomass e.g. temperature, $\mathrm{pH}$ shifts etc. The energy requirements of this scenario depend on the temperature, biogas flow rate, relative size and digestate flow rate in the stripping system.

\section{Scenario 4 - Pre-digestion ammonia removal}

The operation of scenario 4 requires selection of a design residence time and therefore of the relative volumes of the hydrolysis reactor (or mixing tank) and the ammonia stripping reactor. In a particular installation, once these volumes have been set the residence times then depend only on the OLR of the system. This scenario assumes that hydrolysis of proteins and ammonia release occurs in a relatively small hydrolysis reactor. Whilst there is evidence that this could occur in the low $\mathrm{pH}$ environment found in this type of reactor [25], initial experiments with food waste showed that only $15 \%$ of the potential TAN concentration is released in a low $\mathrm{pH}$ short retention time reactor, probably due to $\mathrm{pH}$ inhibition [26]. It is likely that some form of $\mathrm{pH}$ control, through chemical additions or digestate recycle, would be needed for effective ammonia release in the hydrolysis step. Recycling large volumes of digestate to the hydrolysis reactor would make this scenario similar to scenario 3.

In order to model this scenario it was first necessary to calculate digester TAN concentrations for various degrees of hydrolysis in the first step, to establish the TAN concentration entering the stripping reactor; 
and to determine the amount of time the digestate spends in the stripping reactor. Stripping in this case was modelled under the same conditions as scenario 1 (as per run 20.1/20.2) assuming an ammonia removal time constant of 4 hours based on a temperature of $70^{\circ} \mathrm{C}$ and a biogas flow rate of $0.375 \mathrm{I} \mathrm{I}^{-1} \mathrm{~min}^{-1}$. The results are shown in Figure 10, and it can be seen that the effectiveness of the hydrolysis process is the most critical factor: if the nitrogen remains as proteins or amino acids throughout the hydrolysis step it cannot be removed by the stripping stage, and therefore ends up as ammonia in the digester.

For further modelling of scenario 4 a particular design case was chosen based on residence time $s$ in the hydrolysis and stripping reactor of 2 days and 8 hours respectively at an OLR up to $6 \mathrm{~kg} \mathrm{VS} \mathrm{m}^{-3} \mathrm{~d}^{-1}$. The calculation steps, which assume both hydrolysis and TAN release are $1^{\text {st }}$ order with a time constant of 0.35

$\mathrm{d}^{-1}$, are shown in table 3. The results show digester TAN concentrations between 750-3379 $\mathrm{mg} \mathrm{N} \mathrm{I}^{-1}$ corresponding to removals of $88-44 \%$ relative to a digester without stripping. Figure 9 shows the results compared with the other removal scenarios. The results for an OLR of $5 \mathrm{~kg} \mathrm{VS} \mathrm{m}^{-3} \mathrm{~d}^{-1}$ require a hydrolysis tank $9.2 \%$ and stripping reactor $0.77 \%$ of the size of the main digester. If the size of the hydrolysis and stripping reactors is doubled (giving residence times of 4 days and 16 hours respectively at $5 \mathrm{~kg} \mathrm{VS} \mathrm{m}^{-3} \mathrm{~d}^{-1}$ ) the performance of the system improves, giving TAN removals of $93-68 \%$ relative to no intervention.

Of the scenarios modelled the applicability of pre-digestion ammonia stripping is associated with the most uncertainty. There is insufficient experimental data to predict whether ammonia can be fully released in a hydrolysis reactor, without excessive use of chemicals to control $\mathrm{pH}$. Furthermore large concentrations of VFA would be expected in the effluent from the hydrolysis reactor which could impact the stripping process as was observed in the experimental work. Further experimental work is required to verify this application. However pre-digestion shows most promise in terms its degree of operational flexibility, allowing the hydrolysis and stripping systems to be designed independently: this would permit operational control of the TAN and therefore free ammonia concentration in the digester to that required for a particular OLR. None of the other scenarios provide this since they are all subject to operational limits: scenarios 1 and 3 from the deactivation of biomass due to the high temperature stripping process and scenario 2 by the temperature of stripping in situ and the relatively short HRT at high OLR.

\section{Conclusion}

In all experimental runs it was possible to reduce the TAN concentration in the digestate by biogas stripping, which suggests that this technology may be viable as a tool for ammonia management in AD to relieve toxicity and manage digestate ammonia concentration. The kinetic of the TAN removal process was shown to approximate $1^{\text {st }}$ order decay over a wide range of conditions of temperature and gas flow rate. At 35 and $55{ }^{\circ} \mathrm{C}$ the removal time constants were in the order of 600 hours, whereas at $70{ }^{\circ} \mathrm{C}$ this could be reduced to around $15-17$ hours at a suitable flow rate. With $\mathrm{pH}$ adjustment by the addition of $10 \mathrm{M} \mathrm{NaOH}$ the time constant could be further reduced, to 3.9 hours at $70^{\circ} \mathrm{C}$. The main interfering factor in ammonia removal appeared to be high concentrations of VFA which led to a characteristic small initial pH increase followed by a sharp swing to a lower $\mathrm{pH}$, resulting in cessation of the ammonia removal process and leaving TAN concentration of around $4000 \mathrm{mg} \mathrm{N}^{-1}$ in the digestate.

The results of the modelling showed that ammonia removal in an integrated process was achievable in all of scenarios considered. In situ ammonia removal showed the greatest ammonia removal over a wide range of OLR, whereas pre-digestion ammonia removal allowed the most operational flexibility and design since the unit processes of ammonia release, removal and anaerobic digestion could be operated 
independently. Further experimental work is required to design an optimised pre-digestion ammonia removal system. In terms of energy inputs in-situ ammonia removal would involve a large pumping load on the digestion plant which may make the treatment unfeasible. Similarly the other scenarios required varying amounts of additional heat, as stripping would be performed at $70^{\circ} \mathrm{C}$. An energetic analysis of the scenarios would be required before recommendations on larger-scale testing could be made.

\section{Acknowledgements}

The authors wish to thank the UK Government Department for Environment, Food and Rural Affairs (Defra) and the European Union 7th Framework programme for the financial support to carry out this work through grant numbers WR1208 and 241334 (VALORGAS) respectively

\section{References}

[1] Kim, J. K., B. R. Oh, Y. N. Chun and S. W. Kim (2006). "Effects of temperature and hydraulic retention time on anaerobic digestion of food waste." Journal of Bioscience and Bioengineering 102(4): 328-332.

[2] Arthurson, V. (2009). "Closing the Global Energy and Nutrient Cycles through Application of Biogas Residue to Agricultural Land - Potential Benefits and Drawbacks." Energies 2(2): 226-242.

[3] Mata-Alvarez, J. (2003). "Biomethanisation of the Organic Fraction of Municipal Solid Waste." IWA Publishing.

[4] Hashimoto, A. G. (1986). "Ammonia inhibition of methanogenesis from cattle wastes." Agricultural Wastes 17(4): 241-261.

[5] Hansen, K. H., I. Angelidaki and B. K. Ahring (1998). "Anaerobic digestion of swine manure: Inhibition by ammonia." Water Research 32(1): 5-12.

[6] Chen, Y., J. J. Cheng and K. S. Creamer (2008). "Inhibition of anaerobic digestion process: A review." Bioresource Technology 99(10): 4044-4064.

[7] Angelidaki, I., K. Boe and L. Ellegaard (2005). "Effect of operating conditions and reactor configuration on efficiency of full-scale biogas plants." Water science and technology 52(1-2): 189194.

[8] El Hadj, T. B., S. Astals, A. Gali, S. Mace and J. Mata-Alvarez (2009). "Ammonia influence in anaerobic digestion of OFMSW." Water science and technology 59(6): 1153-1158.

[9] Koster, I. W. and G. Lettinga (1984). "The Influence of Ammonium-Nitrogen on the Specific Activity of Pelletized Methanogenic Sludge." Agricultural Wastes 9(3): 205-216.

[10] Banks, C. J., M. Chesshire and A. Stringfellow (2008). "A pilot-scale comparison of mesophilic and thermophilic digestion of source segregated domestic food waste." Water science and technology 58(7): 1475-1481. 
[11] Banks, C. J., M. Chesshire, S. Heaven and R. Arnold (2011). "Anaerobic digestion of sourcesegregated domestic food waste: Performance assessment by mass and energy balance." Bioresource Technology 102(2): 612-620.

[12] Neiva Correia, C., F. Vaz and A. Torres (2008). Anaerobic digestion of biodegradable waste operational and stability para meters for stability control. 5th IWA International Symposium on AD of Solid Wastes and Energy Crops. Hammamet, Tunisa, IWA.

[13] Nielsen, H. B. and I. Angelidaki (2008). "Strategies for optimizing recovery of the biogas process following ammonia inhibition." Bioresource Technology 99(17): 7995-8001.

[14] Wang, Z. J. and C. J. Banks (2003). "Evaluation of a two stage anaerobic digester for the treatment of mixed abattoir wastes." Process Biochemistry 38(9): 1267-1273.

[15] Uludag-Demirer, S., G. N. Demirer and S. Chen (2005). "Ammonia removal from anaerobically digested dairy manure by struvite precipitation." Process Biochemistry 40(12): 3667-3674.

[16] Wett, B. and W. Rauch (2003). "The role of inorganic carbon limitation in biological nitrogen removal of extremely ammonia concentrated wastewater." Water Research 37(5): 1100-1110.

[17] Lei, X. and T. Maekawa (2007). "Electrochemical treatment of anaerobic digestion effluent using a Ti/Pt-IrO2 electrode." Bioresource Technology 98(18): 3521-3525.

[18] Lin, L., S. Yuan, J. Chen, Z. Xu and X. Lu (2009). "Removal of ammonia nitrogen in wastewater by microwave radiation." Journal of Hazardous Materials 161(2-3): 1063-1068.

[19] Wang, S., X. Wu, Y. Wang, Q. Li and M. Tao (2008). "Removal of organic matter a nd a mmonia nitrogen from landfill leachate by ultrasound." Ultrasonics Sonochemistry 15(6): 933-937.

[20] Lei, X., N. Sugiura, C. Feng and T. Maekawa (2007). "Pretreatment of anaerobic digestion effluent with ammonia stripping and biogas purification." Journal of Hazardous Materials 145(3): 391-397.

[21] Saracco, G. and G. Genon (1994). "High temperature ammonia stripping and recovery from process liquid wastes." Journal of Hazardous Materials 37: 191-206.

[22] Bonmati, A. and X. Flotats (2003). "Air stripping of ammonia from pig slurry: characterisation and feasibility as a pre- or post-treatment to mesophilic anaerobic digestion." Waste Management 23(3): 261-272.

[23] De la Rubia, M. A., M. Walker, S. Heaven, C. J. Banks and R. Borja (2010). "Preliminary trials of in situ ammonia stripping from source segregated domestic food waste digestate using biogas: Effect of temperature and flow rate." Bioresource Technology 101(24): 9486-9492.

[24] APHA (2005). Standard Methods for the Examination of Water and Wastewater. 21st edn, American Public Health Association / American Water Works Association / Water Environment Federation, Washington DC, USA. 
[25] Chen, Y., S. Jiang, H. Yuan, Q. Zhou and G. Gu (2007). "Hydrolysis and acidification of waste activated sludge at different pHs." Water Research 41(3): 683-689

[26] Banks, C. J., M. Walker and Y. Zhang (2011). Optimising Processes for the Stable Operation of Food Waste Digestion (WR1208) available online at http://www.organicsrecycling.org.uk/uploads/article1902/Technical\%20report.pdf, Department for Environment, Food and Rural Affairs (Defra), UK

\section{Tables and Figures}


Table 1 Experimental results of batch ammonia stripping experiments with digestates 1 and 2

\begin{tabular}{|c|c|c|c|c|c|c|c|c|c|c|c|}
\hline & $\operatorname{Temp}\left({ }^{\circ} \mathrm{C}\right)$ & Flow Rate $\left(1 \mathrm{I}^{-1} \mathrm{~min}^{-1}\right)$ & $\begin{array}{l}\text { Alkali } \\
\text { addition }\end{array}$ & $\begin{array}{l}\begin{array}{l}\text { Length } \\
\text { of run } \\
\text { (hrs) }\end{array} \\
\end{array}$ & Initial & & Final & & $\begin{array}{l}\text { Time } \\
\text { constant } \\
\text { (hours) }\end{array}$ & $r^{2}$ & $\begin{array}{l}\% \mathrm{~N}-\mathrm{NH}_{3} \\
\text { Removed }\end{array}$ \\
\hline \multicolumn{12}{|c|}{ Digestate 1} \\
\hline & & & & & $\mathrm{pH}$ & $\begin{array}{l}\text { TAN } \\
\left(m g I^{-1}\right)\end{array}$ & $\mathrm{pH}$ & $\begin{array}{l}\text { TAN } \\
\left(\mathrm{mg} \mathrm{N} \mathrm{I}^{-1}\right)\end{array}$ & & & \\
\hline 0.1 & 35 & 0.375 & $\mathrm{~N}$ & 306.3 & 8.43 & 7189 & 8.87 & 4318 & 595.0 & 0.98 & 40 \\
\hline 1.1 & 55 & 0.125 & $\mathrm{~N}$ & 120.1 & 8.46 & 7479 & 8.89 & 6155 & 699.6 & 0.91 & 18 \\
\hline 2.1 & 70 & 0.125 & $\mathrm{~N}$ & 97.5 & 8.70 & 7743 & 8.49 & 446 & 30.7 & 0.96 & 94 \\
\hline 3.1 & 70 & 0.125 & $\mathrm{~N}$ & 118.5 & 8.49 & 7798 & 9.36 & 285 & 32.3 & 0.96 & 96 \\
\hline 4.1 & 70 & 0.375 & $\mathrm{~N}$ & 30.0 & 8.50 & 7764 & 8.86 & 1090 & 15.1 & 0.99 & 86 \\
\hline 5.1 & 70 & 0.250 & $\mathrm{~N}$ & 63.5 & 8.65 & 7810 & 8.89 & 497 & 22.1 & 0.99 & 94 \\
\hline 6.1 & 70 & 0.375 & $\mathrm{~N}$ & 28.8 & 8.50 & 7847 & 8.99 & 1585 & 17.7 & 1.00 & 80 \\
\hline 7.2 & 70 & 0.500 & $N$ & 24.4 & 8.59 & 8076 & 9.04 & 1963 & 17.5 & 1.00 & 76 \\
\hline 8.2 & 70 & 0.625 & $\mathrm{~N}$ & 44.7 & 8.62 & 8245 & 7.98 & 773 & 17.7 & 0.97 & 91 \\
\hline 9.2 & 70 & 0.375 & $\mathrm{Y}$ & 6.3 & 12.18 & 6783 & 10.99 & 1539 & 4.2 & 1.00 & 77 \\
\hline 10.1 & 70 & 0.750 & $\mathrm{~N}$ & 22.7 & 8.45 & 8821 & 9.03 & 6925 & 17.8 & 0.97 & 21 \\
\hline 10.2 & 70 & 0.750 & $\mathrm{~N}$ & 52.0 & 8.45 & 8821 & 8.01 & 470 & 17.1 & 0.97 & 95 \\
\hline 11.1 & 70 & 0.125 & $\mathrm{Y}$ & 64.9 & 10.19 & 7815 & 10.36 & 1706 & 45.2 & 0.93 & 78 \\
\hline 11.2 & 70 & 0.125 & $\mathrm{Y}$ & 89.8 & 10.19 & 7815 & 10.12 & 551 & 36.0 & 0.91 & 93 \\
\hline 12.1 & 70 & 0.250 & $\mathrm{Y}$ & 55.1 & 10.25 & 8134 & 10.30 & 235 & 15.3 & 0.96 & 97 \\
\hline 12.2 & 70 & 0.250 & $\mathrm{Y}$ & 55.3 & 10.25 & 8134 & 10.18 & 202 & 15.0 & 1.00 & 98 \\
\hline 13.1 & 70 & 0.250 & $\mathrm{Y}$ & 71.8 & 11.43 & 5816 & 11.18 & 357 & 27.8 & 0.73 & 94 \\
\hline 13.2 & 70 & 0.375 & $\mathrm{Y}$ & 71.9 & 10.32 & 6232 & 10.41 & 191 & 8.2 & 0.74 & 97 \\
\hline 14.1 & 70 & 0.375 & $\mathrm{Y}$ & 22.8 & 13.86 & 5404 & 11.28 & 281 & 7.8 & 0.96 & 95 \\
\hline 14.2 & 70 & 0.375 & $\mathrm{Y}$ & 22.9 & 13.86 & 5404 & 11.36 & 391 & 8.9 & 0.95 & 93 \\
\hline \multicolumn{12}{|c|}{ Digestate 2} \\
\hline 15.1 & 70 & 0.125 & $\mathrm{~N}$ & 98.5 & 8.20 & 5978 & 8.57 & 1389 & 64.2 & 0.99 & 77 \\
\hline 15.2 & 70 & 0.250 & $\mathrm{~N}$ & 98.5 & 8.20 & 5978 & 7.63 & 1302 & 66.9 & 0.98 & 78 \\
\hline 16.1 & 70 & 0.375 & $\mathrm{~N}$ & 52.9 & 8.13 & 5834 & 8.82 & 1701 & 41.8 & 1.00 & 71 \\
\hline 16.2 & 70 & 0.500 & $\mathrm{~N}$ & 52.9 & 8.13 & 5834 & 8.13 & 1664 & 36.0 & 0.95 & 71 \\
\hline 17.1 & 70 & 0.625 & $\mathrm{~N}$ & 48.5 & 8.24 & 5849 & 7.86 & 1395 & 33.4 & 0.98 & 76 \\
\hline 17.2 & 70 & 0.750 & $\mathrm{~N}$ & 45.3 & 8.24 & 5948 & 7.85 & 1937 & 37.8 & 0.80 & 67 \\
\hline 18.1 & 70 & 0.375 & $Y$ & 18.8 & 12.24 & 4328 & 11.18 & 537 & 9.2 & 0.99 & 88 \\
\hline 18.2 & 70 & 0.500 & $\bar{Y}$ & 18.8 & 12.24 & 4328 & 11.28 & 458 & 8.6 & 0.98 & 89 \\
\hline 19.1 & 70 & 0.375 & $\mathrm{Y}$ & 11.2 & 9.15 & 5258 & 9.96 & 2587 & 15.7 & 0.99 & 51 \\
\hline 19.2 & 70 & 0.500 & $Y$ & 11.2 & 9.06 & 5045 & 9.93 & 2214 & 13.0 & 0.98 & 56 \\
\hline 20.1 & 70 & 0.500 & $\mathrm{Y}$ & 6.3 & 14.56 & 4764 & 12.08 & 1044 & 4.1 & 1.00 & 78 \\
\hline 20.2 & 70 & 0.625 & $Y$ & 6.3 & 14.61 & 4976 & 11.84 & 940 & 3.7 & 0.99 & 81 \\
\hline
\end{tabular}


Table 2 Ammonia concentrations for run 12.1 and 12.2

\begin{tabular}{|l|r|r|}
\hline TAN concentration (mg N l-1) & R1 & R2 \\
\hline Initial Digestate & 8877 & 8877 \\
\hline Final Digestate & 256 & 221 \\
\hline Acid trap & 7681 & 7430 \\
\hline Water trap & 19301 & 20996 \\
\hline Condensate trap & 29227 & 34978 \\
\hline Crystals (with water) & 330 & 240 \\
\hline
\end{tabular}

Table 3 Modelling of pre-digestion hydrolysis and ammonia removal over a range of loading rate from 1-6 $\mathrm{kg} \mathrm{VS} \mathrm{m}{ }^{-3} \mathrm{~d}^{-3}$

\begin{tabular}{|l|r|r|r|r|r|r|}
\hline Organic loading rate (kg VS $\mathbf{~ m}^{-\mathbf{3}} \mathbf{d}^{-1}$ ) & $\mathbf{1}$ & $\mathbf{2}$ & $\mathbf{3}$ & $\mathbf{4}$ & $\mathbf{5}$ & $\mathbf{6}$ \\
\hline Hydrolysis tank size (\% main digester) & 9.2 & 9.2 & 9.2 & 9.2 & 9.2 & 9.2 \\
\hline $\begin{array}{l}\text { Hydraulic retention time of hydrolysis tank } \\
\text { (days) }\end{array}$ & 20 & 10 & 6.7 & 5 & 4 & 3.3 \\
\hline $\begin{array}{l}\text { TAN concentration in hydrolysis tank (input to } \\
\text { ammonia stripper, mg N l-1) }\end{array}$ & 5250 & 4667 & 4200 & 3818 & 3500 & 3231 \\
\hline Ammonia stripper size (\% of main digester) & 0.77 & 0.77 & 0.77 & 0.77 & 0.77 & 0.77 \\
\hline Batch time of ammonia stripper (hours) & 40 & 20 & 13.3 & 10 & 8 & 6.7 \\
\hline TAN concentration after stripping (mg N l-1) & 0.24 & 31 & 150 & 313 & 474 & 610 \\
\hline TAN concentration in digester (mg N l-1) & 750 & 1365 & 1948 & 2495 & 2974 & 3379 \\
\hline $\begin{array}{l}\text { Ammonia removal (\% removal c.f. no } \\
\text { intervention) }\end{array}$ & 87.5 & 77.3 & 67.5 & 58.4 & 50.4 & 43.7 \\
\hline
\end{tabular}




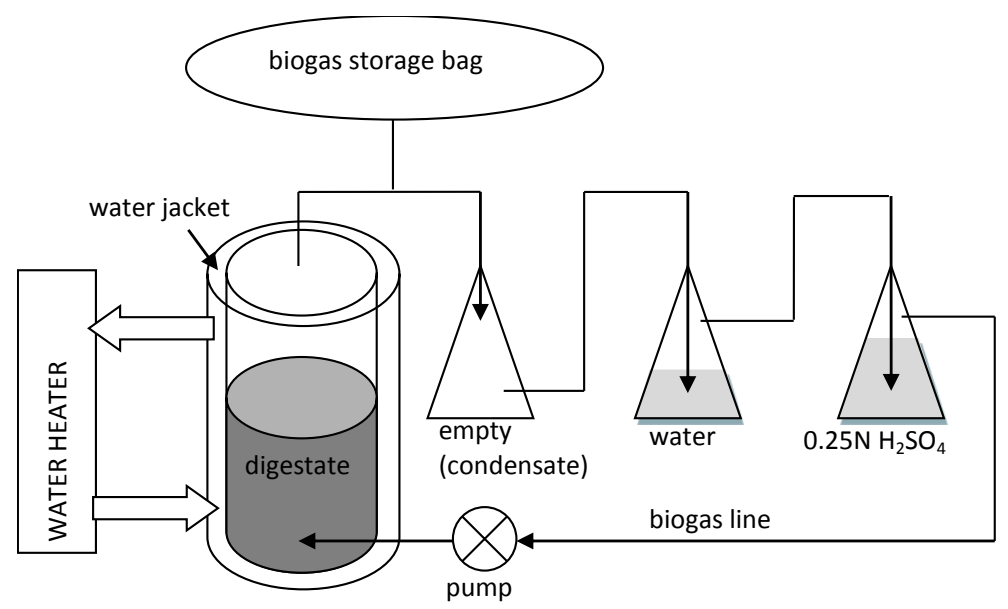

Figure 1 Ammonia stripping equip ment

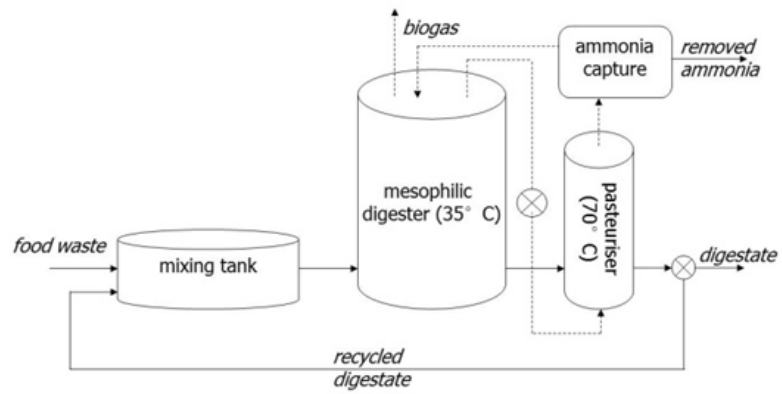

Scenario 1 Post digestion ammonia removal

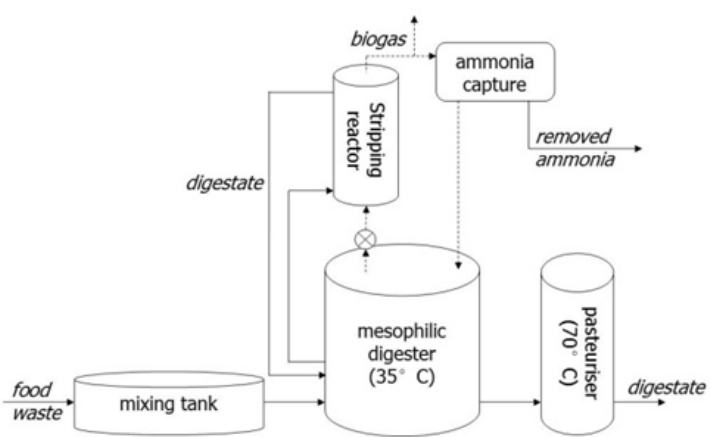

Scenario 3 Side-stream ammonia removal

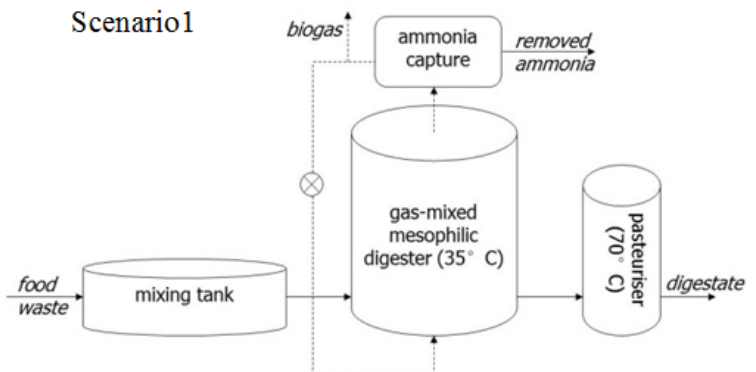

Scenario 2 In situ ammonia removal

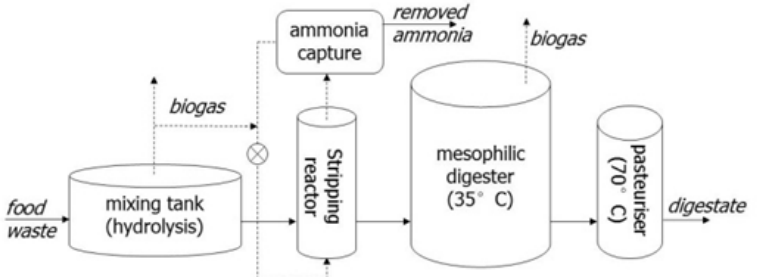

Scenario 4 Pre-digestion ammonia removal

Figure 2 Ammonia removal scenarios modelled 


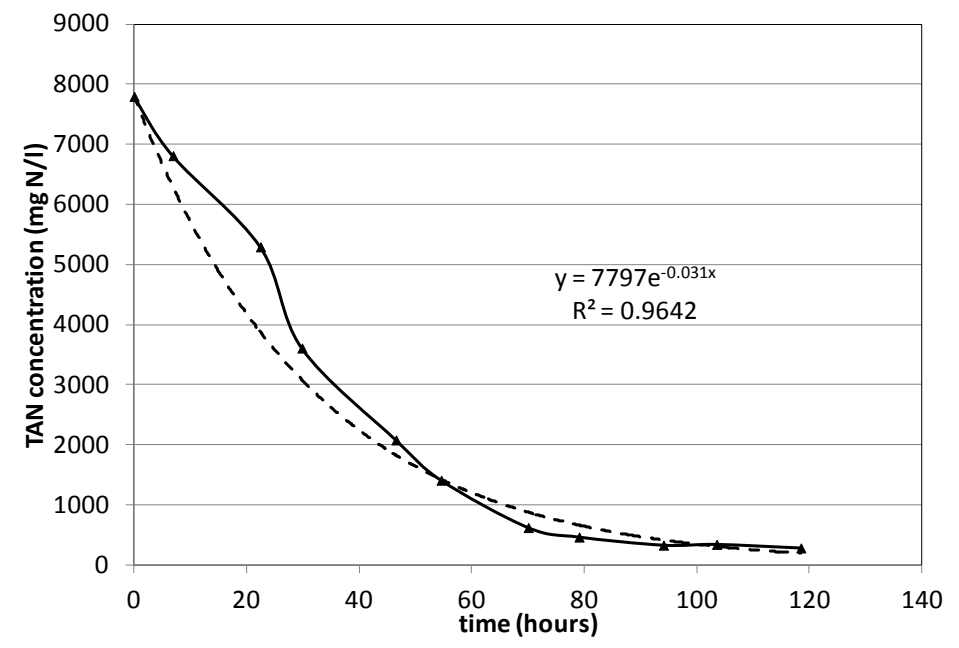

Figure 3 Exponential fit of experimental data $\left(70^{\circ} \mathrm{C}\right.$, gas flow rate $0.12511^{-1} \mathrm{~min}^{-1}$, no $\mathrm{pH}$ modification $)$ to an exponential decay coefficient

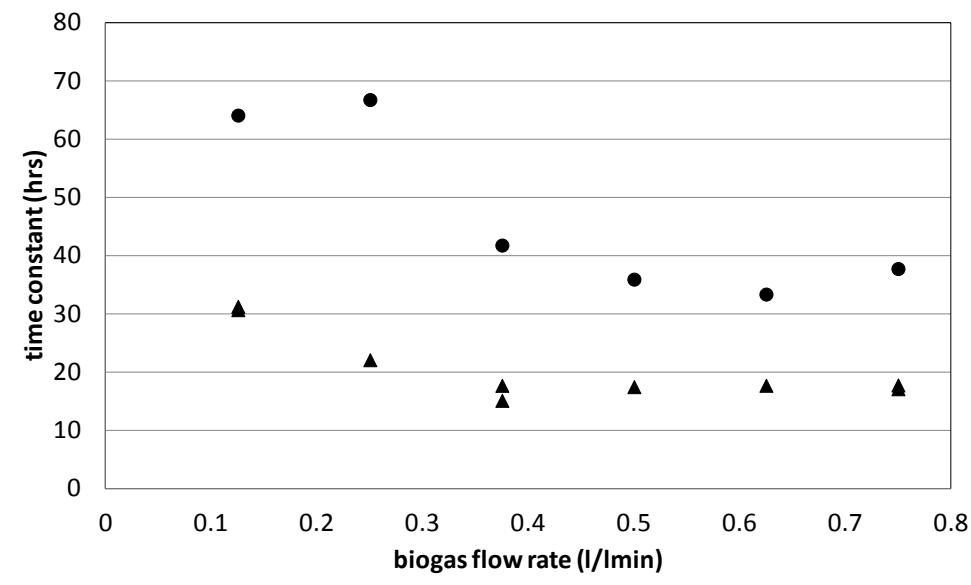

\ Digestate 1 - Digestate 2

Figure 4 Variation in the ammonia removal time constant with biogas flow rate for D1 and D2

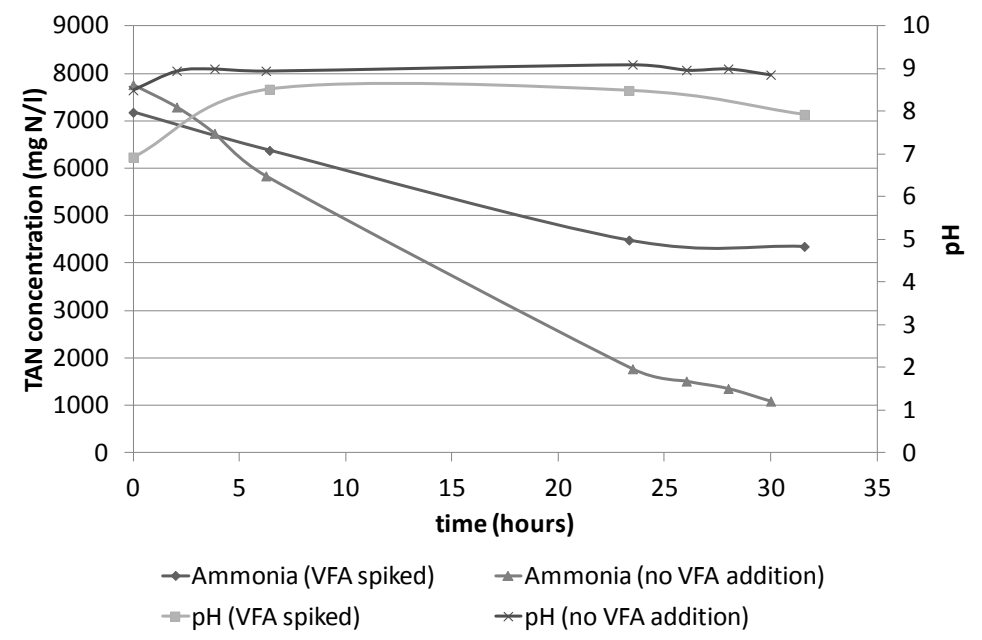

Figure 5 Effect of VFA on ammonia stripping $\left(70^{\circ} \mathrm{C}\right.$, gas flow rate $0.37511^{-1} \mathrm{~min}^{-1}$, no $\mathrm{pH}$ modification $)$ 


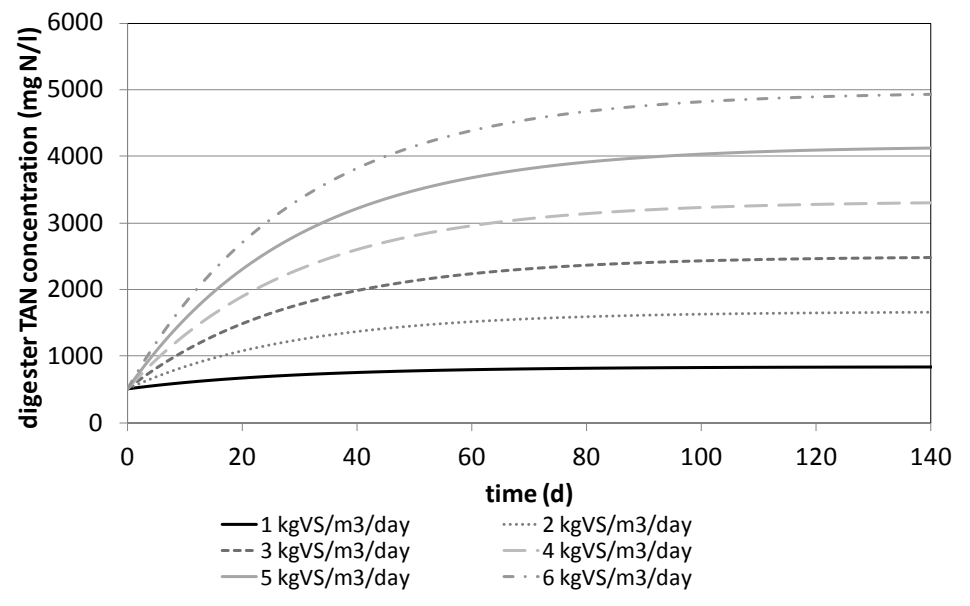

Figure 6 Results from the modelling of scenario 1 at loading rates of $1-6 \mathrm{~kg} \mathrm{VS} \mathrm{m}^{-3} \mathrm{~d}^{-1}$

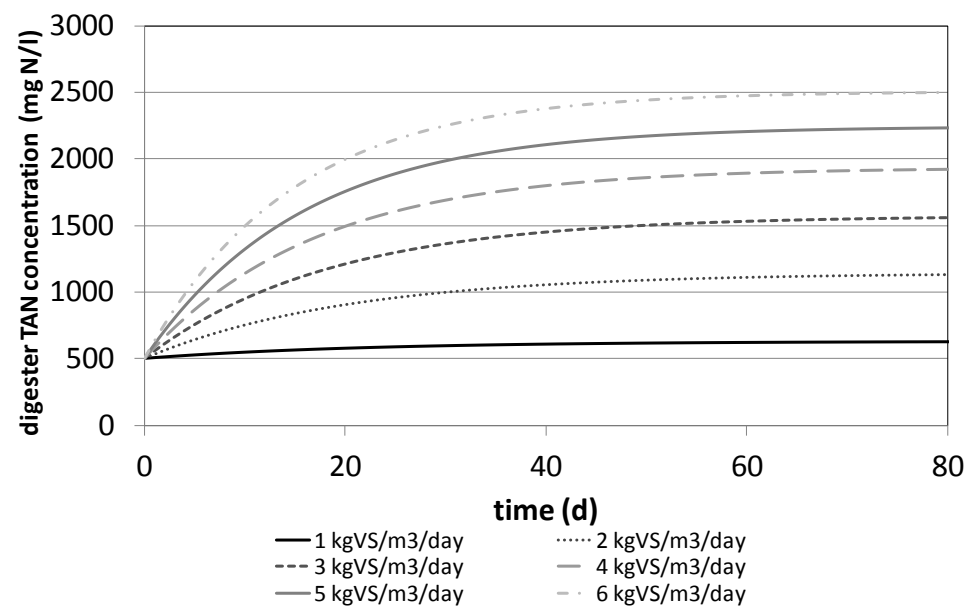

Figure 7 Results fro $\mathrm{m}$ the modelling of scenario 2 at loading rates of $1-6 \mathrm{~kg} \mathrm{VS} \mathrm{m}^{-3} \mathrm{~d}^{-1}$

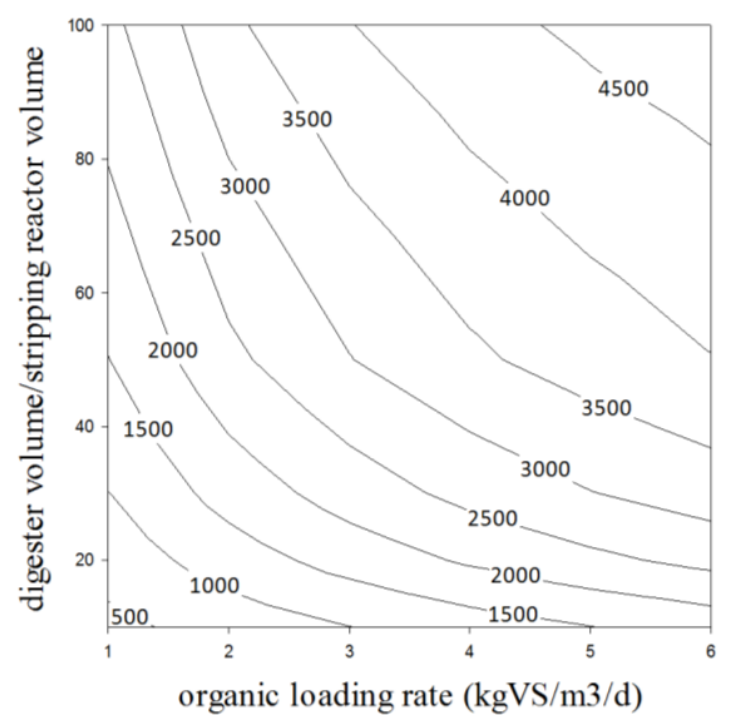

Figure 8 Digester TAN concentration $\left(\mathrm{mg} \mathrm{N} \mathrm{I}^{-1}\right)$ at different organic loading rates using a side stream stripping process between $1 / 10$ to $1 / 100$ of the volume of the digester. 


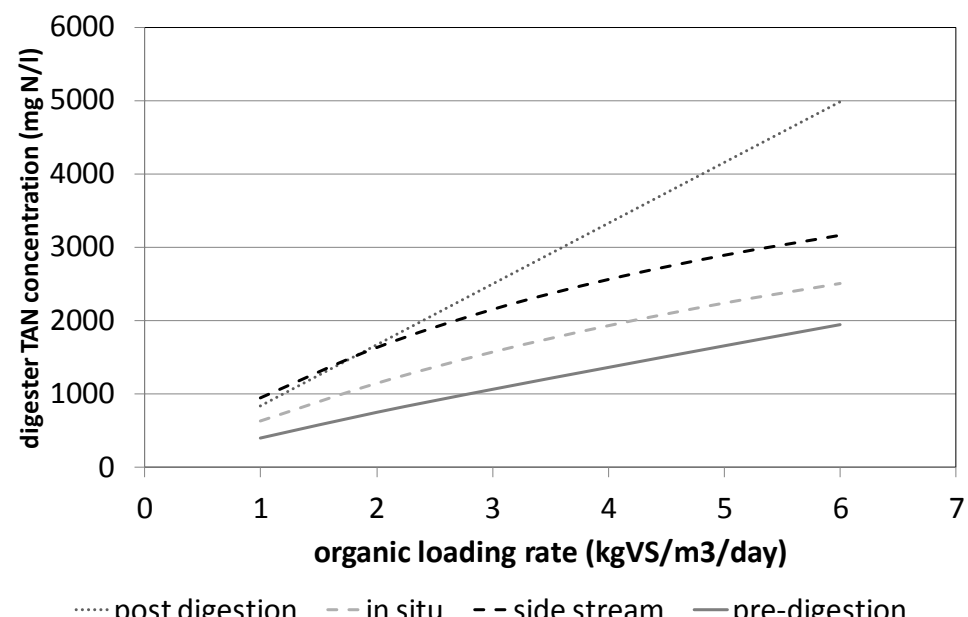

Figure 9 Comparis on of digester ammonia concentrations with the four ammonia removal scenarios at organic loading rates of $1-6 \mathrm{~kg} \mathrm{VS} \mathrm{m}^{-3} \mathrm{~d}^{-1}$

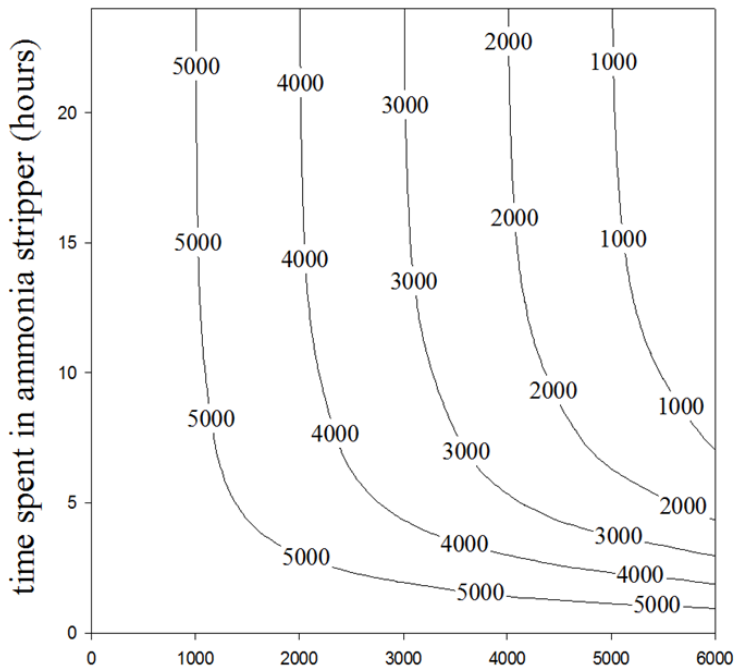

TAN concentration after hydrolysis $\left(\mathrm{mg} \mathrm{N}^{-1}\right)$

Figure 3 Contour plot of digester TAN concentration $\left(\mathrm{mg} \mathrm{N}^{-1}\right)$ for differing degrees of ammonia release during hydrolysis and time spent in a pre-digestion ammonia stripper. 